\title{
DIALLEL ANALYSIS FOR GRAIN YIELD AND MINERAL ABSORPTION RATE OF SOYBEANS GROWN IN ACID BRAZILIAN SAVANNAH SOIL1
}

\author{
CARLOS ROBERTO SPEHAR ${ }^{2}$
}

\begin{abstract}
High available aluminium and low levels of calcium below the ploughed zone of the soil are limiting factors for agricultural sustainability in the Brazilian Cerrados (Savannahs). The mineral stresses compound with dry spells effect by preventing deep root growth of cultivated plants and causes yield instability. The mode of inheritance for grain yield and mineral absorption ratio of a diallel cross in soybeans [Glycine $\max$ (L.) Merrill] grown in high and low Al areas was identified. Differences among the genotypes for grain yield were more evident in the high $\mathrm{Al}$, by grouping tolerant and non-tolerant genotypes for their respective arrays in the hybrids. A large proportion of genetic variance was additive for grain yield and mineral absorption ratio in both environments. High heritability values suggest that soybeans can be improved by crosses among Al-tolerant genotypes, using modified pedigree, early generation and recurrent selection schemes.
\end{abstract}

Index terms: aluminium, calcium, cultivar, additive, dominance, breeding.

\section{ANÁLISE DIALÉLICA DA PRODUÇÃO DE GRÃOS E TAXA DE ABSORÇÃO MINERAL NA SOJA CULTIVADA EM SOLO ÁCIDO DOS CERRADOS BRASILEIROS}

\begin{abstract}
RESUMO - A presença de alumínio e reduzidos níveis de cálcio abaixo da camada arável do solo são fatores que ameaçam a sustentabilidade agrícola nos cerrados brasileiros. Esses fatores limitantes agravam o efeito de estresses hídricos, por reduzir o crescimento radicular em profundidade nas plantas cultivadas, e resultam na instabilidade produtiva. Identificou-se o modo de herança da produção de grãos e a taxa de absorção de nutrientes em soja [Glycine max (L.) Merrill], com cruzamento dialélico entre nove cultivares, sob baixa e elevada disponibilidade de alumínio. As diferenças entre os genótipos mostraram-se mais evidentes nesta última, pelo agrupamento dos respectivos híbridos no dialelo. Grande proporção da variância genética para a produção de grãos e taxa de absorção mineral é devida a efeitos aditivos. A elevada herdabilidade sugere a possibilidade de selecionar por produtividade em presença dos estresses minerais nos cruzamentos entre genótipos tolerantes, com o uso dos métodos genealógico modificado, teste em gerações iniciais e seleção recorrente.
\end{abstract}

Termos para indexação: alumínio, cálcio, variedade, aditivo, dominância, melhoramento genético.

\section{INTRODUCTION}

The Brazilian Savannahs (Cerrados) cover vast areas of ferralsols in the tropics, which have free aluminium (Al) and scarcity of calcium (Ca) below the ploughed zone of the soil. These major constraints, that prevent deep root growth of cultivated plants, compounded by bad rainfall distribution, can cause yield fluctuations. The

\footnotetext{
${ }^{1}$ Accepted for publication on July 31, 1998.

${ }^{2}$ Agronomist, Ph.D., Embrapa-Centro de Pesquisa Agropecuária dos Cerrados (CPAC), Caixa Postal 08223, CEP 73301-970 Planaltina, DF, Brazil. E-mail: spehar@cpac.embrapa.br
}

genetics of tolerance to these hindrances must be understood to achieve yield stability of cultivated plants (Spehar, 1994c, 1994d, 1995b).

Amendments tend to concentrate in the ploughed layer of cultivated savannah soils and only in the long run nutrients leach down into the subsoil, given there is no physical impediment. Cultivated plants, selected in these environments, possess some tolerance to toxic $\mathrm{Al}$ and to low levels of $\mathrm{Ca}$, for deep root growth (Foy et al., 1992; Spehar, 1994a, 1995a). If the genetic factors that condition $\mathrm{Al}$ and low-Ca tolerances are identified, it is expected that yield in more tolerant cultivars will be buffered to weather instability. 
Controlled environment experiments that comprise the use of problem-soils and of nutrient solution have been used in varietal screening and in genetic and breeding studies as an indirect means to improve plants to mineral stress tolerance. In field selection of Al-tolerant cultivars, there are major concerns on mineral element interactions and the confounding effects of uncontrolled environmental factors, e.g., erratic rainfall distribution and frequency to dry spells, even though natural selection has contributed to crop adaptation (Foy et al., 1992; Spehar, 1994c). It can be questioned whether $\mathrm{Al}$ affects grain yield by reducing root growth and absorption of nutrients; or, if its interaction with $\mathrm{Ca}$ and magnesium $(\mathrm{Mg})$ diminishes their absorption and movement in the plant, causing reduction in photosynthetic rate and, consequently, grain yield (Ohki, 1986; Devine et al., 1990; Foy et al., 1992; Rengel, 1992; Wilkinson \& Duncan, 1993; Spehar, 1995a). Genotypic differences to Al tolerance have been identified by measuring mineral element absorption and root growth in hydroponics (Spehar, 1994c, 1995a).

The mode of inheritance for important agronomic traits has been identified by hybridisation schemes, one of them is the diallel analysis. Griffing (1956) developed the analysis into combining ability evaluation, whereas Mather \& Jinks (1982) method enables to estimate genetic components and heritability.

In diallel cross, Al-free, field experiments with maize (Gorsline et al., 1968), sorghum (Gorz et al., 1987) and soybeans (Spehar, 1995a), differential absorption of nutrients by the plant has shown quantitative inheritance as measured by the additivedominance model.

Diallel analysis for $\mathrm{Al}$ tolerance experiments in maize indicated quantitative inheritance, with additive effects more important than dominance in both cases (Pandey et al., 1994). In soybeans, predominant additive effects for mineral composition suggested the use of modified pedigree and recurrent selection schemes for crop improvement (Spehar, 1994c, 1995a). The genetics of grain yield and its relationship to mineral element absorption in soybeans, however, remain to be studied (Foy et al., 1992; Spehar, 1995a).
This study aimed to identify the mode of inheritance for grain yield in soybeans by an experiment with a diallel cross in a high and in a low $\mathrm{Al}$ areas and relate it to mineral absorption ratio.

\section{MATERIAL AND METHODS}

The soybean cultivars IAC-2, IAC-5, IAC-7, IAC-8, IAC-9, UFV-1, Vx5-281.5, Biloxi and FT-Cristalina were chosen for a diallel cross, based on their performance in field and hydroponics experiments (Spehar, 1994a, 1994d). Their genealogy and reaction to Al has already been described (Spehar, 1995b). The $F_{1}$ 's were advanced into $F_{2}$ 's and seeds of true crosses, identified by marker genes, were pooled together for every cross among the cultivars. The experiment was conducted on hill plots, using $15 \mathrm{~F}_{2}$ seeds per hill, in two levels of liming, with three replications of randomised complete-block design.

The two experimental areas were limed and fertilised in the following manner: 1) $500 \mathrm{~kg} / \mathrm{ha}$ dolomitic limestone ( $100 \% \mathrm{CaCO}_{3}$ equivalent), $150 \mathrm{~kg} / \mathrm{ha} \mathrm{P}, 75 \mathrm{~kg} / \mathrm{ha} \mathrm{K}$ and $40 \mathrm{~kg} / \mathrm{ha}$ of slow release micronutrients source, FTE-BR-12; 2) $4000 \mathrm{~kg} / \mathrm{ha}$ dolomitic limestone $(100 \%$ $\mathrm{CaCO}_{3}$ equivalent) and the other sources of nutrients in the same amounts as in the first case. All amendments were broadcast applied and incorporated into the soil with a rotovator up to $20 \mathrm{~cm}$ depth. The chemical analyses of soil samples collected after the experiment, at $0-20 \mathrm{~cm}$ depth, indicated $\mathrm{pH}\left(\mathrm{H}_{2} \mathrm{O}\right.$ 1:1) 5.1 and 5.7; $\mathrm{Al} 0.97$ and $0.10 \mathrm{cmol}_{\mathrm{c}} / \mathrm{kg} ; \mathrm{Ca}+\mathrm{Mg} 1.65$ and $3.56 \mathrm{cmol}_{\mathrm{c}} / \mathrm{kg} ; \mathrm{P} 3.1$ and $3.4 \mathrm{mg} / \mathrm{kg} ; \mathrm{K} 0.13$ and $0.15 \mathrm{cmol}_{\mathrm{c}} / \mathrm{kg}$, respectively. Calcium carbonate equivalent is the acid neutralising capacity of lime expressed as weight percentage of calcium carbonate (Tisdale et al., 1985).

Foliar samples were collected, according to a method previously described, to eliminate possible differences of leaf position on the plant (Spehar, 1995a). At maturity the plants in each plot were harvested separately for both high and low Al experiment. The leaf mineral composition ratios (high/low Al) and grain yield/plant data of the two environments and their ratio were statistically analysed, according to Griffing (1956) and Mather \& Jinks (1982) procedures. Due to absence of maternal effect, the data were analysed as half diallel and the reciprocals provided another set of replications for mineral element absorption rate.

\section{RESULTS AND DISCUSSION}

The combining ability analysis of variance for grain yield in the high $\mathrm{Al}$, in the low $\mathrm{Al}$ and the ratios 
between the two environments for both grain yield and mineral absorption are presented in Table 1. The general combining ability (GCA), which measured the additive effects of genes, was superior in magnitude to the specific combining ability (SCA). The ratio $\mathrm{GCA} / \mathrm{SCA}$ was largest in the low $\mathrm{Al}$ environment, and lowest in the high $\mathrm{Al}$ environment and in the ratio high/low Al. Despite the difference in magnitude of the ratios, these results suggest that inheritance for grain yield in soybeans is controlled largely by additive effects. The ratio, which excluded a possible interference of varietal yielding potential,

TABLE 1. General and specific combining abilities (GCA, SCA) for grain yield in high Al (H), in low Al (L) and the ratio $\left(H / L^{*} 100\right)$ for yield and mineral absorption of the diallel cross.

\begin{tabular}{|c|c|c|c|c|c|c|}
\hline Character & Source of variation & D.F. & M.S. & $\mathrm{F}$ & $\mathrm{p}$ & GCA/SCA \\
\hline \multicolumn{7}{|c|}{ Grain yield } \\
\hline \multirow{3}{*}{$\operatorname{High} \mathrm{Al}(\mathrm{H})$} & GCA & 8 & 23.09 & 13.54 & $<0.001$ & \\
\hline & SCA & 36 & 7.97 & 4.67 & 0.001 & 2.9 \\
\hline & Error & 44 & 1.70 & & & \\
\hline \multirow[t]{3}{*}{ Low Al (L) } & GCA & 8 & 89.93 & 22.56 & $<0.001$ & \\
\hline & $\mathrm{SCA}$ & 36 & 10.93 & 2.74 & 0.004 & 8.2 \\
\hline & Error & 44 & 3.98 & & & \\
\hline \multirow[t]{3}{*}{$\mathrm{H} / \mathrm{L}$} & GCA & 8 & 338.17 & 7.91 & $<0.001$ & \\
\hline & $\mathrm{SCA}$ & 36 & 112.10 & 2.70 & 0.003 & 3.0 \\
\hline & Error & 44 & 1.70 & & & \\
\hline \multicolumn{7}{|c|}{ Mineral absorption } \\
\hline \multirow[t]{3}{*}{ Potassium } & GCA & 8 & 176.70 & 5.79 & 0.006 & \\
\hline & SCA & 36 & 73.11 & 2.40 & 0.005 & 2.4 \\
\hline & Error & 132 & 30.50 & & & \\
\hline \multirow[t]{3}{*}{ Calcium } & GCA & 8 & 472.90 & 9.14 & 0.001 & \\
\hline & SCA & 36 & 138.30 & 2.67 & 0.004 & 3.4 \\
\hline & Error & 132 & 51.70 & & & \\
\hline \multirow[t]{3}{*}{ Magnesium } & GCA & 8 & 358.30 & 13.28 & $<0.001$ & \\
\hline & $\mathrm{SCA}$ & 36 & 63.01 & 2.33 & 0.004 & 5.7 \\
\hline & Error & 132 & 27.00 & & & \\
\hline \multirow[t]{3}{*}{ Iron } & GCA & 8 & 6763.61 & 6.73 & 0.003 & \\
\hline & SCA & 36 & 2726.90 & 2.71 & 0.004 & 2.5 \\
\hline & Error & 132 & 1004.42 & & & \\
\hline \multirow[t]{3}{*}{ Aluminium } & GCA & 8 & 16920.03 & 7.69 & 0.002 & \\
\hline & SCA & 36 & 5722.70 & 2.60 & 0.004 & 3.0 \\
\hline & Error & 132 & 2200.61 & & & \\
\hline \multirow[t]{3}{*}{ Manganese } & GCA & 8 & 20488.12 & 1.97 & 0.150 & \\
\hline & $\mathrm{SCA}$ & 36 & 17800.10 & 1.71 & 0.025 & 1.1 \\
\hline & Error & 132 & 10403.00 & & & \\
\hline \multirow[t]{3}{*}{ Zinc } & GCA & 8 & 4046.51 & 12.83 & $<0.001$ & \\
\hline & SCA & 36 & 991.30 & 3.14 & 0.002 & 4.1 \\
\hline & Error & 132 & 315.40 & & & \\
\hline \multirow[t]{3}{*}{ Copper } & GCA & 8 & 1031.33 & 4.73 & 0.012 & \\
\hline & SCA & 36 & 756.00 & 3.47 & 0.002 & 1.4 \\
\hline & Error & 132 & 217.02 & & & \\
\hline
\end{tabular}


confirms the predominance of additive effects. Similarly, Pandey et al. (1994) found larger additive than dominance effects for Al tolerance in maize, measured by grain yield.

The mean value for the grain yield in both environments and the ratios for both grain yield and mineral element absorption are presented in Table 2 .

The arrays whose common parent was Biloxi had a great range for grain yield, although the mean was low in both environments. This result may be explained by its low agronomic performance in the cerrados. The lowest value for UFV-1 and the highest for IAC-9, in the high-Al area, confirms the reaction of respective parental cultivar to Al (Spehar, 1994a, 1994c). However, the array with Biloxi as a common parent did not provide clear cut results and yet it has shown to be Al-tolerant (Foy et al., 1992). This is interpreted that the gene combinations for yield are independent from the ones for Al-tolerance, as shown by the result in the absence of $\mathrm{Al}$ and the ratio high/low $\mathrm{Al}$. In the latter IAC-9 and Biloxi gave highest results as compared to the lowest by UFV-1 and suggest that it is more accurate to use (Foy et al., 1992) if only Al tolerance is the character being selected. Thus, it is expected that crossing among adapted, high-yielding genotypes shall enhance soybeans to mineral stresses.
The higher absorption ratios for $\mathrm{Al}$ and iron in all genotypes, including intolerant UFV-1, than for tolerant Biloxi, confirmed, in part the results of previous work (Spehar, 1995a). This suggests that the roots grow deep in the subsoil, thus absorbing more A1, although IAC-9, another tolerant cultivar, did not show the same trend in all crosses. For $\mathrm{Ca}$ and $\mathrm{Mg}$, however, the results between UFV-1 and the tolerant cultivars Biloxi and IAC-9 were more contrasting. UFV-1 and its crosses suffered possible $\mathrm{Al}$ damage in the roots, explaining the lower $\mathrm{Ca}$ and $\mathrm{Mg}$ absorption by hybrids of this cultivar in the high-Al environment. When $\mathrm{Al}$ was not a limiting factor in the ploughed layer of the soil, the roots of susceptible genotypes were more active and differences among the crosses expected to be less evident (Spehar, 1995a). The average ratios for K, $\mathrm{Cu}, \mathrm{Mn}$ and $\mathrm{Zn}$ were not associated with specific array but with hybrid combination.

The results of the regression analysis for covariance $\left(\mathrm{W}_{\mathrm{r}}\right)$ by variance $\left(\mathrm{V}_{\mathrm{r}}\right)$ indicate that the test for $b$ (the regression slope) was significantly different from one and that the additive-dominance model is not sufficient to explain the genetic differences in these genotypes for grain yield in both environments and the ratio. The mineral element absorption ratios were explained by the model for $\mathrm{K}, \mathrm{Mg}$, iron (Fe), $\mathrm{Al}$, and $\mathrm{Zn}$ (Table 3). Ca, similarly

TABLE 2. Array means for grain yield (g/plant) in high $\mathrm{Al}(\mathrm{H})$, low $\mathrm{Al}(\mathrm{L})$ and the ratio $\left(\mathrm{H} / \mathrm{L}^{*} 100\right)$ for yield and mineral absorption.

\begin{tabular}{lrrrrrrrrr}
\hline \multirow{2}{*}{ Character } & \multicolumn{7}{c}{ Array } \\
\cline { 2 - 9 } & IAC-9 & IAC-2 & UFV-1 & IAC-5 & IAC-8 & Vx5-281-5 & IAC-7 & Biloxi & FT-Cristalina \\
\hline \multicolumn{7}{c}{ Grain yield } \\
$\mathrm{H}$ & 13.36 & 12.51 & 10.1 & 11.85 & 11.52 & 11.50 & 12.47 & 10.93 & 12.25 \\
$\mathrm{~L}$ & 22.96 & 22.62 & 20.62 & 22.97 & 21.83 & 20.60 & 23.63 & 17.53 & 23.83 \\
$\mathrm{H} / \mathrm{L}$ & 58.53 & 55.38 & 49.13 & 52.45 & 53.20 & 57.52 & 53.57 & 61.93 & 51.78 \\
& & & & \multicolumn{7}{c}{ Mineral element absorption ratio } & & & \\
$\mathrm{K}$ & 110.7 & 107.7 & 113.8 & 110.1 & 110.0 & 110.7 & 107.7 & 107.4 & 110.8 \\
$\mathrm{Ca}$ & 89.8 & 93.1 & 81.0 & 88.7 & 90.4 & 87.9 & 88.4 & 87.1 & 86.5 \\
$\mathrm{Mg}$ & 80.8 & 83.5 & 73.2 & 79.2 & 79.2 & 79.0 & 78.6 & 81.1 & 77.3 \\
$\mathrm{Fe}$ & 168.9 & 174.2 & 162.0 & 166.6 & 164.5 & 149.5 & 176.5 & 139.5 & 148.0 \\
$\mathrm{Al}$ & 212.3 & 225.7 & 204.1 & 212.0 & 202.9 & 187.7 & 223.4 & 168.3 & 180.0 \\
$\mathrm{Mn}$ & 394.7 & 449.3 & 433.8 & 428.1 & 421.7 & 393.0 & 424.4 & 377.1 & 376.2 \\
$\mathrm{Zn}$ & 184.7 & 163.2 & 169.4 & 183.8 & 194.7 & 169.4 & 190.5 & 172.3 & 175.1 \\
$\mathrm{Cu}$ & 147.4 & 141.1 & 138.4 & 138.8 & 137.3 & 143.8 & 147.4 & 133.3 & 133.6 \\
\hline
\end{tabular}


to field and hydroponics experiments, showed to be fully explained by a more complex model (Spehar, 1989).

The estimates of genetic parameters are listed in Table 4. Negative values of $\mathrm{H}_{1}-\mathrm{H}_{2}$ indicated that there was no difference between allele frequency in the high and the ratio high/low Al for grain yield, whereas unequal allele frequency over all loci was found for mineral absorption ratios. The estimate of the type of allele with most frequency was given by the ratio $\left[\left(4 \mathrm{DH}_{1}\right)^{1 / 2}+\mathrm{F}\right] /\left[\left(4 \mathrm{DH}_{1}\right)^{1 / 2}-\mathrm{F}\right]$; values greater than one indicate more dominant than recessive alleles in both environments but not in the ratio high/low Al for grain yield. For $\mathrm{K}, \mathrm{Fe}$ and $\mathrm{Al}$, more dominant than recessive alleles predominated for mineral composition in the nine cultivars of the diallel. The square root of $\mathrm{H}_{1} / \mathrm{D}$, that measures the degree of dominance, had values higher than 1 , indicating presence of overdominance, except for the low $\mathrm{Al}$ environment.

These data, apparently contradicting the expected more additive than dominance effects, found in the combining ability analysis, show that gene expression for grain yield and mineral absorption

TABLE 3. Regression of covariance $\left(W_{r}\right)$ on Variance $\left(V_{r}\right)$ for grain yield and mineral composition of the diallel cross.

\begin{tabular}{lcrr}
\hline Character & $\begin{array}{c}\text { Regression } \\
\text { equation }\end{array}$ & $\begin{array}{c}\text { t-test } \\
(\mathrm{b}=1)\end{array}$ & $\mathrm{p}$ \\
\hline \multicolumn{4}{c}{ Grain yield } \\
High Al (H) & $0.46-0.50 \mathrm{~V}_{\mathrm{r}}$ & 7.49 & $<0.001$ \\
Low Al (L) & $4.88+0.40 \mathrm{~V}_{\mathrm{r}}$ & 2.28 & 0.060 \\
$\mathrm{H} / \mathrm{L}$ & $2.04+0.40 \mathrm{~V}_{\mathrm{r}}$ & 2.85 & 0.025 \\
& Mineral absorption & \\
Potassium & $-10.06+0.71 \mathrm{~V}_{\mathrm{r}}$ & 1.76 & 0.130 \\
Calcium & $10.35+0.15 \mathrm{~V}_{\mathrm{r}}$ & 2.99 & 0.023 \\
Magnesium & $-4.76+0.91 \mathrm{~V}_{\mathrm{r}}$ & 0.33 & $>0.500$ \\
Iron & $-54.52+0.39 \mathrm{~V}_{\mathrm{r}}$ & 1.79 & 0.130 \\
Aluminium & $13.89+0.41 \mathrm{~V}_{\mathrm{r}}$ & 1.70 & 0.150 \\
Manganese & $-28.67-0.01 \mathrm{~V}_{\mathrm{r}}$ & 7.56 & $<0.001$ \\
Zinc & $-147.43+0.73 \mathrm{~V}_{\mathrm{r}}$ & 0.96 & 0.380 \\
Copper & $110.59+0.41 \mathrm{~V}_{\mathrm{r}}$ & 6.99 & $<0.001$ \\
\hline
\end{tabular}

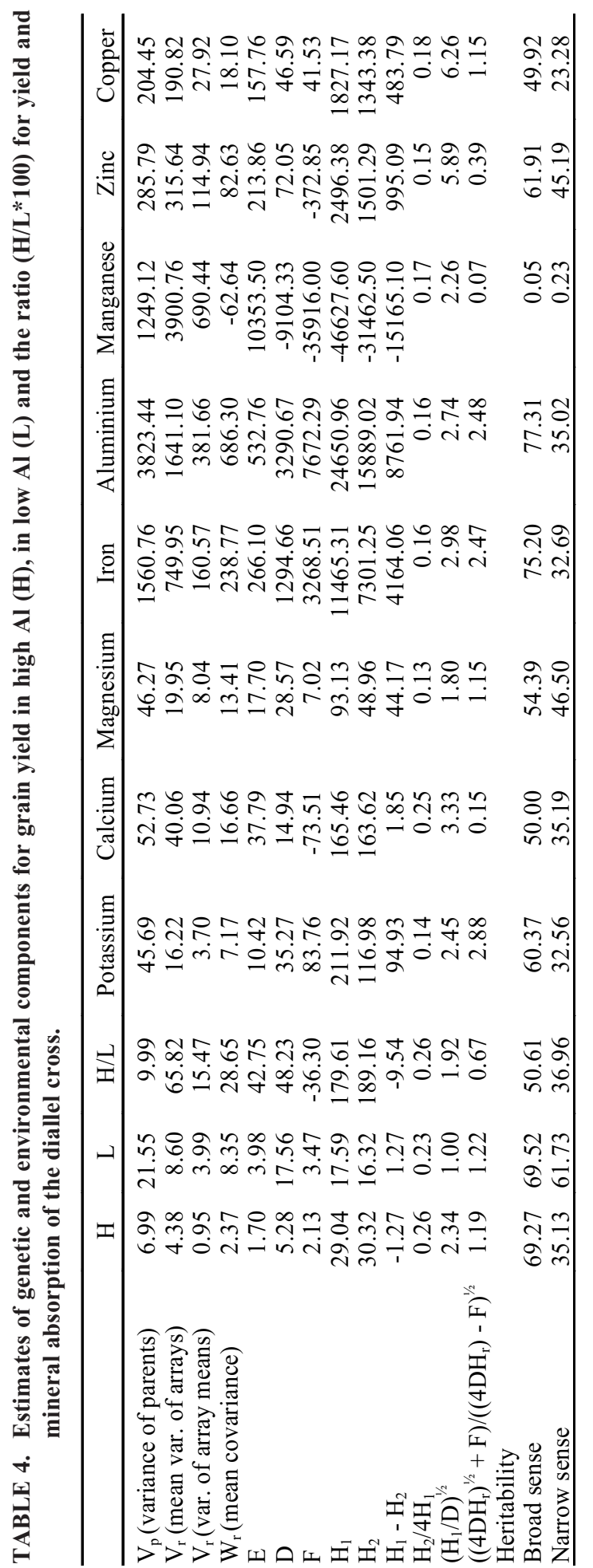


ratio is highly dependent on the plant environment. Departure from additive was related to some crosses that had a better performance than the parents, when they were both tolerant, one intolerant and the other tolerant and both intolerant, for grain yield and mineral absorption ratio.

The calculated heritabilities for grain yield indicated that broad sense was high in each environment and intermediate in the ratio, while narrow sense was low except in the low-Al environment. High broad sense heritabilities were found for $\mathrm{K}, \mathrm{Al}, \mathrm{Fe}$ and $\mathrm{Zn}$; for $\mathrm{Ca}, \mathrm{Mg}$ and $\mathrm{Cu}$, they had intermediate values; the genetic differences for Mn seemed rather complex. Narrow sense heritabilities were of low values for all elements. Similar results were obtained for mineral element uptake in maize, forage sorghum and soybeans (Gorsline et al., 1968; Gorz et al., 1987; Spehar, 1995a). The lack of fitness of the additive-dominance model may have been a consequence of possible residual heterozigosity in the parental cultivars. Indication of genetic variability for low-Ca tolerance within soybean cultivars has already been reported (Spehar \& Galwey, 1997). However, despite the limiting factors, these results suggest that soybeans can be improved for high yield and tolerance to $\mathrm{Al}$ by using modified pedigree, early generation testing on hill plot and recurrent selection, following hybridisation of superior individuals (Spehar, 1994b).

The best recombinants can be identified in hydroponics experiments and shall form a gene pool to be employed in field tests for the acquisition of new cultivars to enhance the prospect for sustainable agricultural systems (Spehar, 1994d, 1995a).

\section{CONCLUSIONS}

1. Grain yield is an efficient evaluation of genetics to Al tolerance in soybeans and the ratio high-/low-Al allows to separate the intrinsic differences in yield among the genotypes.

2. The predominantly additive and, in a minor scale, dominance effects for grain yield and mineral absorption ratios is exploited by modified pedigree, early generation and recurrent selection schemes to improve soybeans for acid soil tropical cultivation.

\section{REFERENCES}

DEVINE, T.E.; BOUTON, J.H.; MABRAHTU, T. Legume genetics and breeding for stress tolerance and nutrient efficiency. In: BALIGAR, V.C.; DUNCAN, R.R. (Eds.). Crops as enhancers of nutrient use. New York: Academic Press, 1990. p.211-252.

FOY, C.D.; DUKE, J.A.; DEVINE, T.E. Tolerance of soybean germplasm to an acid Tatum subsoil. Journal of Plant Nutrition, v.15, p.527-547, 1992.

GORSLINE, G.W.; THOMAS, W.I.; BAKER D.E. Major gene inheritance of $\mathrm{Sr}-\mathrm{Ca}, \mathrm{Mg}, \mathrm{K}, \mathrm{P}, \mathrm{Zn}, \mathrm{Cu}$, $\mathrm{B}, \mathrm{Al}-\mathrm{Fe}$, and Mn concentrations in corn, Zea mays L. [S.1.]: Pennsylvania State University, 1968. (Pennsylvania State Bulletin, 746).

GORZ, H.J.; HASKINS, F.A.; PEDERSEN, J.F.; ROSS, W.M. Combining ability effects for mineral elements in forage sorghum hybrids. Crop Science, v.27, p.216-219, 1987.

GRIFFING, B. Concept of general and specific combining ability in relation to diallel crossing systems. Australian Journal of Biological Science, v.9, p.463-493, 1956.

MATHER, K.; JINKS, J.L. Biometrical genetics. 3.ed. London: Chapman and Hall, 1982. 454p.

OHKI, K. Aluminium stress on sorghum growth and nutrient relationships. Plant and Soil, v.98, p.195-202, 1986.

PANDEY, S.; CEBALLOS H.; MAGNAVACA, R.; BAHIA FILHO, A.F.C.; DUQUE-VARGAS, J.; VINASCO, L.E. Genetic tolerance to soil acidity in tropical maize. Crop Science, v.34, p.1511-1514, 1994.

RENGEL, Z. The role of calcium in aluminium toxicity. New Phytologist, v.121, p.499-513, 1992.

SPEHAR, C.R. Aluminium tolerance of soybean genotypes in short term experiments. Euphytica, v.76, p.73-80, 1994a.

SPEHAR, C.R. Breeding soybeans to the low latitudes of Brazilian Cerrados (Savannahs). Pesquisa Agropecuária Brasileira, Brasília, v.29, n.8, p.1167-1180, ago. 1994b

SPEHAR, C.R. Diallel analysis for mineral element absorption in tropical adapted soybeans [Glycine max (L) Merrill]. Theoretical and Applied Genetics, v. 90, n. 5 , p. $707-713,1995$ a. 
SPEHAR, C.R. Field screening of soya bean [(Glycine $\max (\mathrm{L}$.$) Merrill] germplasm for aluminium$ tolerance by the use of augmented design. Euphytica, v.76, n.3, p.203-213, 1994c.

SPEHAR, C.R. Impact of strategic genes in the soybean [Glycine $\max (\mathrm{L}$.$) Merrill] on agricultural$ development in the Brazilian Tropical Savannahs. Field Crops Research, v.41, p.141-146, 1995b.

SPEHAR. C.R. Screening soybean germplasm for aluminium tolerance using cluster analysis. Pesquisa Agropecuária Brasileira, Brasília, v.29, n.1, p.113-122, jan. 1994d.
SPEHAR, C.R. The genetics of aluminium tolerance in soya beans [Glycine $\max (\mathrm{L})$ Merrill]. Cambridge: University of Cambridge, 1989. Ph.D. Thesis. 123p.

SPEHAR, C.R.; GALWEY, N.W. Screening soya beans [Glycine $\max (\mathrm{L})$ Merrill] for calcium efficiency by root growth in low-Ca nutrient solution. Euphytica, v.94, p.113-117, 1997.

TISDALE, S.L.; NELSON, W.L.; BEATON, J.D. Soil fertility and fertilizers, 4.ed. New York: MacMillan, 1985. 694p.

WILKINSON, R.E.; DUNCAN, R.R. Calcium (Ca-45) absorption inhibition by aluminum $\left(\mathrm{Al}^{3+}\right)$ in sorghum roots. Journal of Plant Nutrition, v.16, p.235-240, 1993. 